\title{
The Danube, an Empire Boundary River: Settlements, Invasions, Navigation, and Trade Pathway
}

\author{
Kenneth R. Olson'1 (D), Edward Krug2 \\ ${ }^{1}$ Department of Natural Resources and Environmental Sciences, College of Agricultural, Consumer, and Environmental Sciences, \\ University of Illinois, Urbana, USA \\ ${ }^{2}$ Illinois State Water Survey, Champaign, USA \\ Email:krolson@illinois.edu
}

How to cite this paper: Olson, K.R. and Krug, E. (2020) The Danube, an Empire Boundary River: Settlements, Invasions, Navigation, and Trade Pathway. Journal of Water Resource and Protection, 12, 884897.

https://doi.org/10.4236/jwarp.2020.1210051

Received: September 21, 2020

Accepted: October 27, 2020

Published: October 30, 2020

Copyright $\odot 2020$ by author(s) and Scientific Research Publishing Inc. This work is licensed under the Creative Commons Attribution International License (CC BY 4.0).

http://creativecommons.org/licenses/by/4.0/

\begin{abstract}
The Danube River basin was home to some of the world's earliest human cultures such as the Danubian Neolithic cultures including the Linear Pottery culture. The Vucedol culture was famous for ceramics during the third millennium BC. Early settlement required fortresses and castles to be built on the Danube River to defend the settlements from invading forces. These included the Persia, Roman and Ottoman empires. Cities included Vienna, Budapest, Belgrade and Ruse. The risks include stream capture, settlement, invasions, navigation, trade, pollution, industrial and urban wastewater, over fishing, food insecurity, locks and dams, shoreline erosion and flooding. The primary objective was to document the settlement history on the Danube River which became Eastern Europe's pathway for settlement, invasions, navigation and trade in the Danube basin has put the river at risk for more than 2500 years. River capturing of the Danube by the Rhine River has reduced the length and flow of the Danube. The Danube River has had a huge economic, social and environmental impact on 10 European countries. However, with 10 countries sharing the river it has been difficult to manage and mitigate the risks and threats to the Danube River and its water quality.
\end{abstract}

\section{Keywords}

Locks, Dams, Flooding, Shoreline Erosion, Fishing, Drinking Water, Ottoman, Roman, Hydroelectric, Pirate Attacks

\section{Introduction}

The Danube River played an important role in the political evolution and set- 
tlement patterns of central and southeastern Europe [1] with riverbanks lined with fortresses and castles. The river formed the boundary between great empires, and the river served as a vital commercial highway between nations. During the $7^{\text {th }}$ Century, the Danube became the pathway for the transport of invading forces. A traditional trade route in Europe since ancient times, the Danube continues to be an important trade artery.

Today, approximately $2415 \mathrm{~km}$ of the Danube River are navigable. The river is an important source of drinking water and hydropower. It has been harnessed for hydroelectric power particularly along the headwaters. The cities along its banks include the national capitals of Budapest (Hungary), Vienna (Austria), and Belgrade (Serbia) which have depended upon the Danube for their economic development [2]. The River has long been celebrated in music.

After the Volga, the Danube is Europe's second longest river. It is located in Eastern and Central Europe and was once a long-standing frontier of the Roman Empire. Originating near the Black Forest in Germany, the Danube presently flows southeast for $2850 \mathrm{~km}$ and passes through 10 countries which is more than any other river in the world: Slovakia, Austria, Hungary, Serbia, Germany, Croatia, Romania, Bulgaria, Moldova and Ukraine, draining into the Black Sea. Its watershed extends into 9 additional countries (Figure 1).

The Danube has a drainage basin of some $817,000 \mathrm{sq} \mathrm{km}$ with the river basin expanding unevenly along its length. The 300 branching tributaries form a dense, deep water river network with more than 30 navigable tributaries. The river width varies unevenly along its length. It covers about 47,000 square $\mathrm{km}$ at the Inn River confluence, 210,000 sq km after joining with the Drava River. More than half of the entire Danube basin tributaries collect two-thirds of the total runoff volume from the Alps and other mountain areas.

The primary objective is to document the natural and anthropic risks to the Danube River including stream capture, settlement, invasions, navigation and trade. Environmental risks include pollution, industrial and urban wastewater, over fishing, a threat to food supply, urban development, locks and dams, shoreline erosion, flooding.

\subsection{Geology}

The Rhine and Danube rivers, compete for water in southern Germany. The Rhine is the only river headwater in the Alps Mountains and flows north towards the North Sea. The Rhine River is at a much lower elevation than the Danube River. The headwater percolates into underground channels at the Danube Sink in the Swabian Alb. The Swabian Alb is largely shaped by porous limestone with many sinkholes. The catchment subsurface river transports much of the upper Danube River water to the Rhine River. During the summer, the Danube carries little river water.

Most of this water resurfaces only $12 \mathrm{~km}$ south at the Aachtopf, Germany. The average flow feeding the Rhine is at a rate of 8500 liters per second. The European 


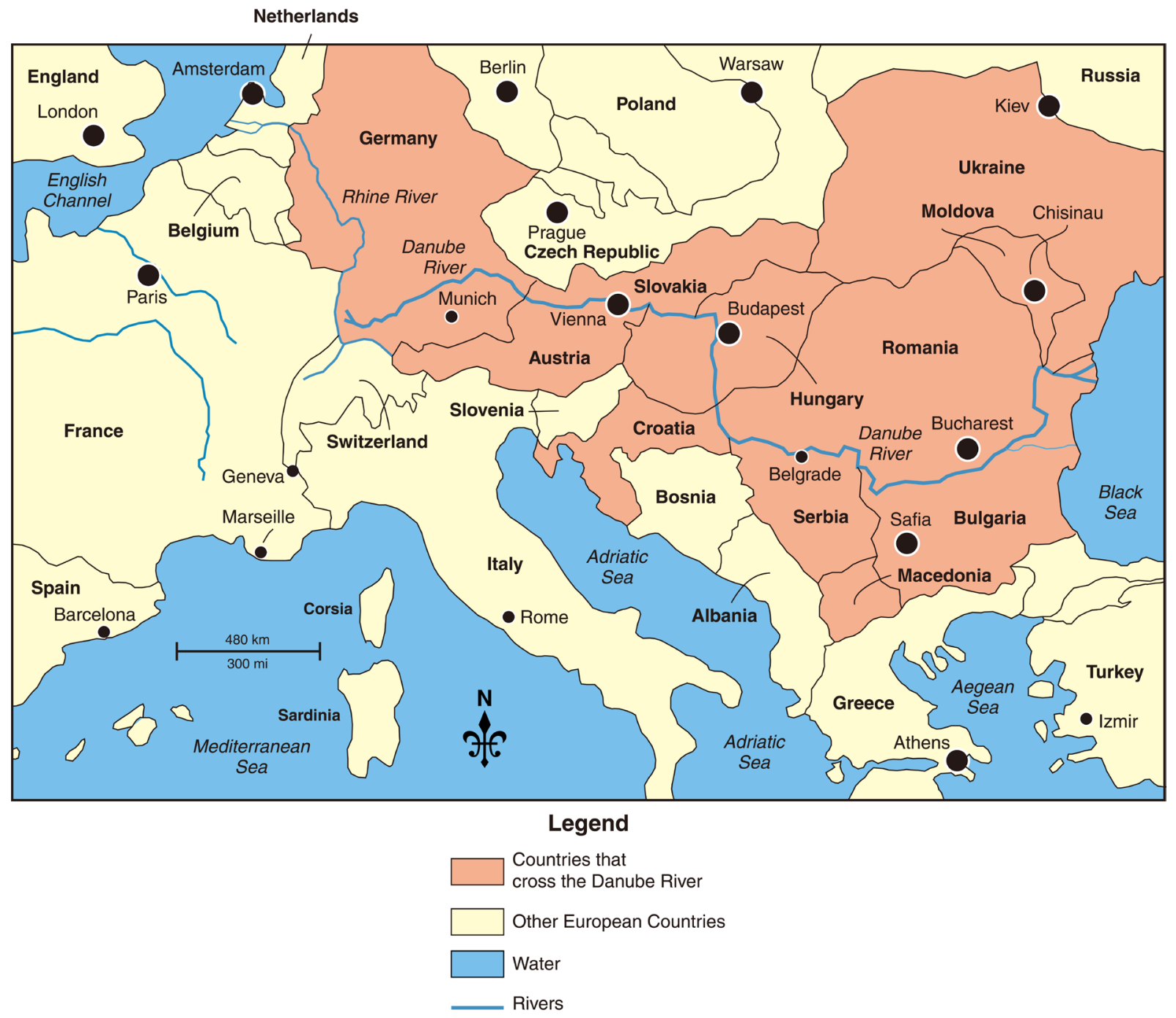

Figure 1. Map of the Danube as it winds its way through 10 countries. Map by Mic Greenberg.

Water Divide applies only for those waters that pass beyond this point, and only during the days of the year when the Danube carries enough water volume to flow east over the limestone sinkholes in the Danube Sink. Since such large volumes of underground water erode much of the surrounding limestone, it is estimated that the Danube upper course will one day be lost to the Rhine as a result of stream capture [1]. The Rhine started at the southwestern tip of the Black Forest before the last ice age in the Pleistocene. The waters from the Alps were carried east by the so-called Urdonau or ancient Danube. Parts of this ancient "RIVERBED" can still be seen in the Swabian Alb landscape. Much of the upper Rhine valley had been eroded and the headwaters from the Alps changed direction and began flowing to the Rhine [3]. The upper Danube River's headwater river is much smaller than the ancient river.

\subsection{Hydrology}

The constant shift of deposits in different parts of the riverbed forms shoals. The 
river carries considerable quantities of solid quartz grains. Draglines are constantly at work to maintain the navigational depth in the Sulina Channel between Komarno and Bratislava in Slovakia. The damming of the river has also changed how sediments are transported and deposited. Reservoirs trap the silt load when water is impounded. The water flowing out of the dam has a low sediment load which results in downstream bank erosion.

The climate of each basin segment determines the temperature of the river waters. In the upper segment, the summer water temperature is low since the water is derived from the Alpine snow and glaciers. Summer temperatures vary between $22^{\circ} \mathrm{C}$ and $24^{\circ} \mathrm{C}$ in the middle and lower reaches while winter temperatures drop below freezing. The middle and lower reaches become icebound during severe winters. In the winter ice drift combines with the spring thaw resulting in floating ice blocks which accumulate on the river islands and restrict the river flow often creating major floods.

As a result of the introduction of stream-training equipment, including dams and dikes, the natural regime of river runoff frequently changes. The sediment load of the river is greater in the winter months than the summer. The content of organic matter in the river water and sediment is relatively low. As the river waters flow past industrial and urban areas the pollution level increases. The river chemistry changes with the addition of each city sewage discharge and as a result of agricultural runoff water is high in sediment and nutrients.

\subsection{Cultural History}

Some of the world's earliest human cultures occurred in the Danube basin. During the $7^{\text {th }}$ century BC, Greek sailors reached the lower Danube and sailed upstream in search of trading partners. They named the lower segment Ister. The Danubian Neolithic cultures include the Linear Pottery cultures of the midDanube basin. The third millennium BC Vucedol culture is famous for its ceramics. Darius the Great, King of Persia, crossed the Danube River in the late $6^{\text {th }}$ century BC to invade Scythia. In 336 BC Alexander the Great defeated the Tribal Lian King Syrmus and the northern barbarian Illyracian and Thracian by advancing from Macedonia as far as the Danube. During the time of the Roman Empire the Danube, called the Danuvius, served as the northern boundary and was patrolled by the Roman fleet. The centers of settlements were on the riverbanks including Vienna and later Budapest, Belgrade, and Ruse [2]. The river was a route for the transport of troops and the supplies for the downriver settlements. From AD 37 during the reign of the Emperor Valentinian I the Danubian Limes was the northeastern border of the Roman Empire. The crossing of the Danube under Decebalus into Dacia occurred during the Imperium Romanum. This victory over Dacia enabled the Province of Dacia to be created.

During the Middle Ages, the old castles continued to play an important role (Figure 2). New fortresses such as Werfenstein which were built in the $9^{\text {th }}$ century by Charlemagne. In the $15^{\text {th }}$ century the Ottoman Empire spread from 


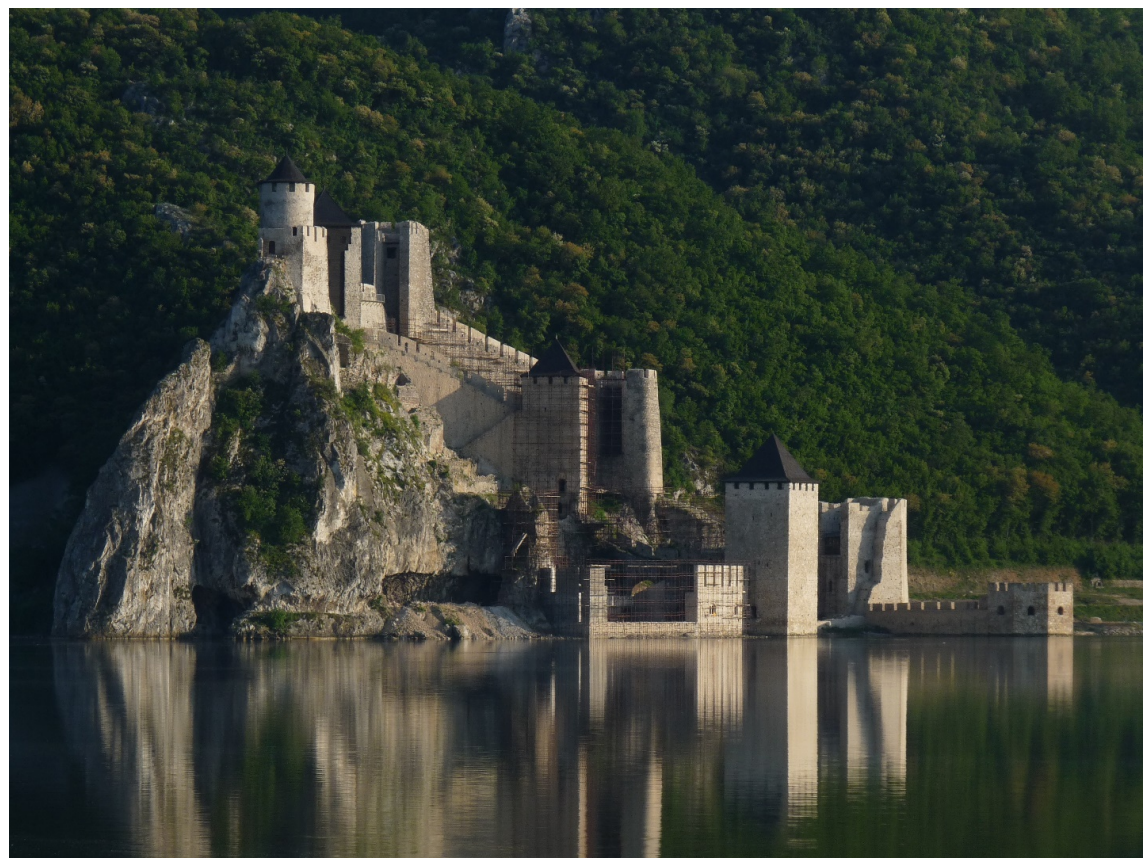

Figure 2. A castle on the Danube close to Belgrade. Photograph by Patricia Krug.

southeastern to central Europe. For defense, the Turks utilized fortresses along the Danube. The Ottoman Empire gained control of the Danube and it became its northern border for centuries after competing for control: first with the Kingdom of Serbia, second Bulgarian Empire, followed by Kingdom of Hungary, the Principality of Wallachia, the Principality of Moldavia, the Austrian Habsburgs, the Polish-Lithuanian Commonwealth, and finally Russian Empire. Many of the Ottoman-Hungarian wars (1366 - 1526) and Ottoman-Habsbury wars (1526 1791) were fought along the Danube.

\subsection{The Route of Emperors and Kings}

The Route of Emperors and Kings got its name from the Holy Roman Emperor Frederick I of Barbarossa and the crusaders as well as from Richard I of England who had been jailed in the Durnstein Castle on the Danube. Over time the Habsburg imperial family traveled the Danube. Many famous castles, palaces, residences and state-run convents where built by the imperial Habsburg family along the river. Today, people can travel the Danube by boat, train, bike on the Danube Bike Trail or walk on the "Donausteig" to visit the UNESCO World Heritage cities of Regensburg, Wachau and Vienna.

\section{Current Danube Watershed, Navigation, Danube Commission and Impact on Environment and Economy of 10 European Countries}

\subsection{Navigation and Canals}

The Austrians were granted the right to navigate the middle and lower Danube in 1616 when the Austro-Turkish treaty was signed in Belgrade. Russia allowed 
the use of the lower Danube in 1774, under the Treaty of Kucuk Kaynarca. A principle that was formulated in the Treaty of Paris of 1856 promoted free navigation along the entire river. The treaty set up the first Danubian Commission with the goal of supervising the river as an international waterway. The final approval of the Danube River Statute was granted by Austria, Germany, Yugoslavia, Bulgaria, Romania, Great Britain, Italy, Belgium, Czechoslovakia, Hungary, and Greece (Figure 1) in 1921 and 1923. The international Danube Commission had authoritative powers, including the right to levy taxes, have its own flag and give diplomatic immunity to its members. The commission-controlled navigation from the town of Ulm to the Black Sea.

During World War II free international navigation was interrupted by conflict. After the Danubian Convention of 1948 navigation resumed. The new Convention provided the Danubian countries the right to participate in a reconstituted Danube Commission. The Danube is navigable by ships from Braila, Romania to the Black Sea. Smaller craft can navigate upstream to Ulm, Wurttemberg, Germany. Many tributaries are also navigable. There were three artificial waterways built on the Danube. The first is the Danube-Tisa-Danube Canal (DTD) in the Banat and Backa region in Serbia. The second is the $64 \mathrm{~km} \mathrm{Da-}$ nube-Black Sea Canal finished in 1984 between Cernavoda and Constanta (Romania) shortening the distance to the Black Sea by $400 \mathrm{~km}$. The third finished, in 1992, is the German Rhine-Main-Danube Canal which is about $171 \mathrm{~km}$ long linking the North Sea to the Black Sea.

Since the completion of the German Rhine-Main-Danube Canal, the Danube has been part of a trans-European waterway from Rotterdam on the North Sea to Sulina, a port on the Black Sea, a total of $3500 \mathrm{~km}$. The Danube was declared one of ten Pan-European transport corridors routes in Eastern and Central Europe in 1994. In 1987 the amount of goods transported on the Danube increased to about 100 million metric tons per year. The NATO bombing of three bridges in Serbia during the Kosovo War in 1999 made transport on the river difficult. Clearance of the resulting debris was completed in 2002. In 2005 a temporary pontoon bridge that restricted navigation was removed.

The Danube flows through a gorge at the Iron Gate (Figure 3) that forms part of the boundary between Romania and Serbia [4]. It contains the Iron Gate I Hydroelectric Power Station dam and was followed by the Iron Gate II Hydroelectric Power Station outside the gorge and $60 \mathrm{~km}$ downstream. On 13 April 2006, the record peak discharge at Iron Gate Dam reached 15,400 m³ $/ \mathrm{s}$.

Between 2010 and 2012 Ukraine shipping companies claimed that their vessels suffered from "regular pirate attacks" on the Serbian and Romanian stretches of the Danube. As defined according to the United Nations Convention on the Law of the Sea, these transgressions were not be considered acts of piracy but rather instances of river robbery. Trading practices have been legal along the river ever since Romania and Bulgaria joined the European Union (EU) in 2007 and Romania became the European border with the Ukraine and Serbia. 
The navigational potential of the Danube (Figure 4) was recognized by the Habsburg Dynasty. Maria Theresa, queen of Hungary and Bohemia from 1740 to 1780 , founded a department to oversee river navigation. In 1830 a riverboat made a first trip from Vienna to Budapest for trading purposes. That trip marked the end of the river's importance as a line of defense and the beginning of its use as a trade pathway. Today navigation on the Danube is regulated by

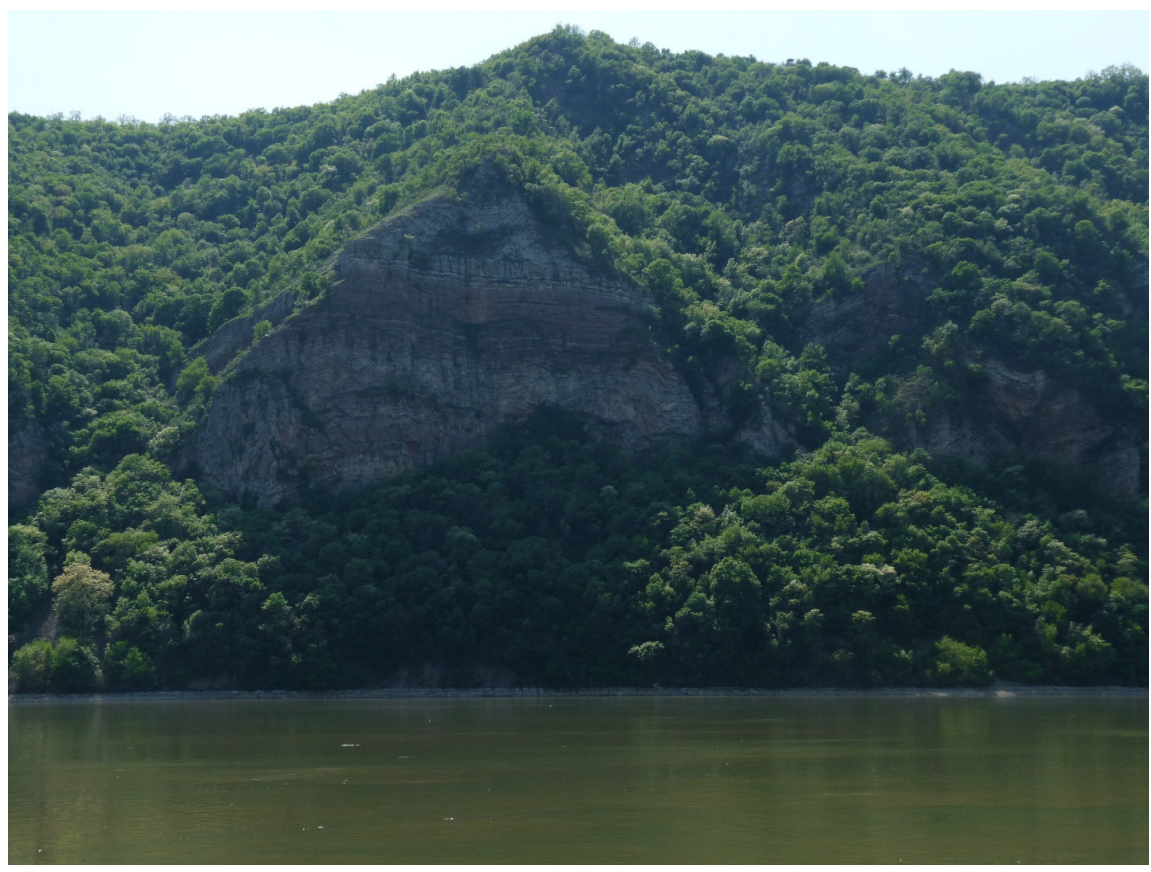

Figure 3. The bedrock control side slope near the Iron Gate. Photograph by Patricia Krug.

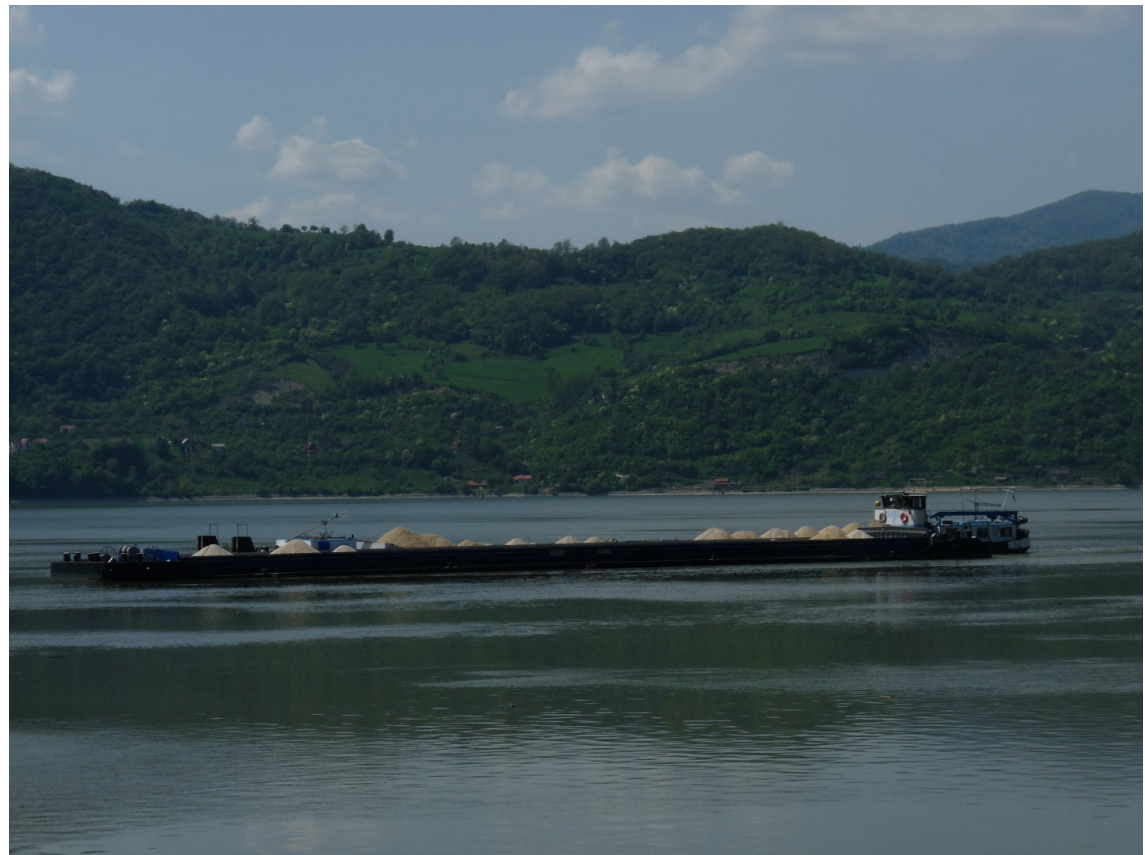

Figure 4. Loaded barges on the Danube River. Photograph by Patricia Krug. 
several international agreements.

The Danube Commission's goal is the maintenance and improvement of the river's navigation conditions. The Commission of seven countries was established in 1948. Members include representatives from Austria, Bulgaria, Croatia, Germany, Hungary, Moldova, Slovakia, Romania, Russia, Ukraine, and Serbia. It meets regularly to consider items provided in the commission's working plans. The 1856 and 1921 Paris Conferences established for the first time an international regime to safeguard free navigation on the Danube. The Commission includes riparian and non-riparian states.

\subsection{Danube Delta}

The Danube Delta is the largest river delta in the European Union (EU). The northern part of the Danube Delta lies in Romania. The left bank of the Chilia arm is situated in Ukraine (Odessa Oblast) [4]. The approximate land surface is $4152 \mathrm{~km}^{2}$, of which $3446 \mathrm{~km}^{2}$ is in Romania. The combined territory of the Danube Delta reaches $5165 \mathrm{~km}^{2}$ if the lagoon of Razim-Sinoe is included, $1015 \mathrm{~km}^{2}$ of which $865 \mathrm{~km}^{2}$ of water surface located south of the delta proper, their combined territory of the Danube Delta. Since 1991 the Delta has been a UNESCO World Heritage Site and a Ramsar Site. The Danube Delta is the best-preserved river delta in Europe. Its lakes and marshes support 45 freshwater fish species. Its wetlands support over 300 species of migratory birds, including the endangered pygmy cormorant (Phalacrocorax pygmaeus). Canalization and drainage schemes, such as the Bystroye Canal, are considered a potential threat.

\subsection{The Economy}

The Danube is of great economic importance to the 10 countries (Figure 1) that it borders or flows through: Ukraine, Moldova, Romania, Serbia, Croatia, Hungary, Bulgaria, Slovakia, Austria, and Germany [5]. These countries use the river for freight transport, the generation of hydroelectricity, industrial and residential water supplies, hydroelectricity, fishing, and irrigation. The most important economic use (highest and best use) of the Danube is for the movement of freight. Among the major port cities are Izmayil, Ukraine; Galați and Braila, Romania; Ruse, Bulgaria; Belgrade, Serbia; Budapest, Hungary; Bratislava, Slovakia; Vienna, Austria; and Regensburg, Germany.

With the construction of a series of canals and an improvements made by dredging, river traffic has increased considerably since World War II. The most important canals include the Danube-Black Sea Canal, which runs from Cernovada, Romania, to the Black Sea and provides a more direct and easily navigable link. In 1999 the Danube Canal which links the Danube to the Rhine was completed.

The upper section of the Danube has high valley walls which makes good dam sites (Figure 3 ) and can be tapped for power. One of the largest hydroelectric 
projects, the Djerdap High Dam and the Iron Gate power station [6], was built jointly by Yugoslavia and Romania. These most difficult stretches on the river are now navigable. Danube waters are used by industry at Vienna, Budapest (Figure 5 and Figure 6), Belgrade, and Ruse. The primary areas of irrigation are along the river are in Slovakia, Serbia, Hungary, and Bulgaria. Because of the

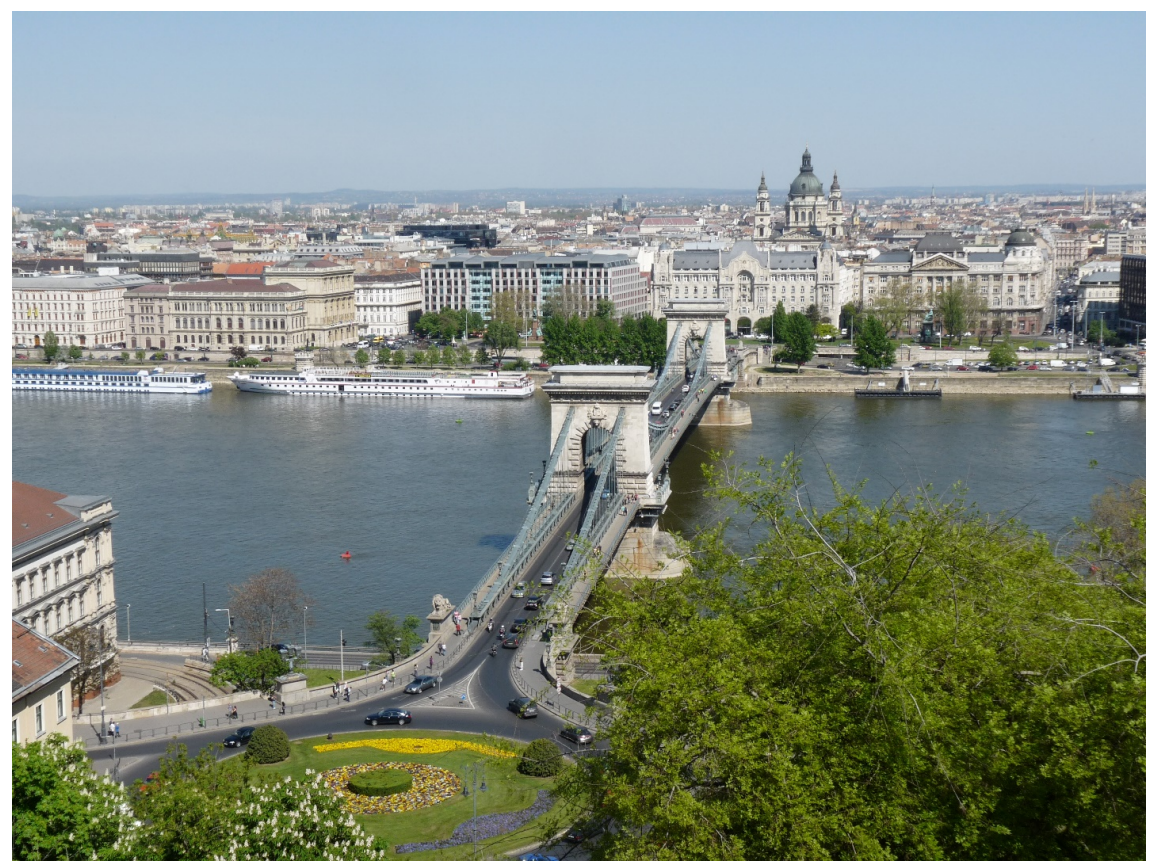

Figure 5. The Danube River at Budapest with island and boats. Photograph by Patricia Krug.

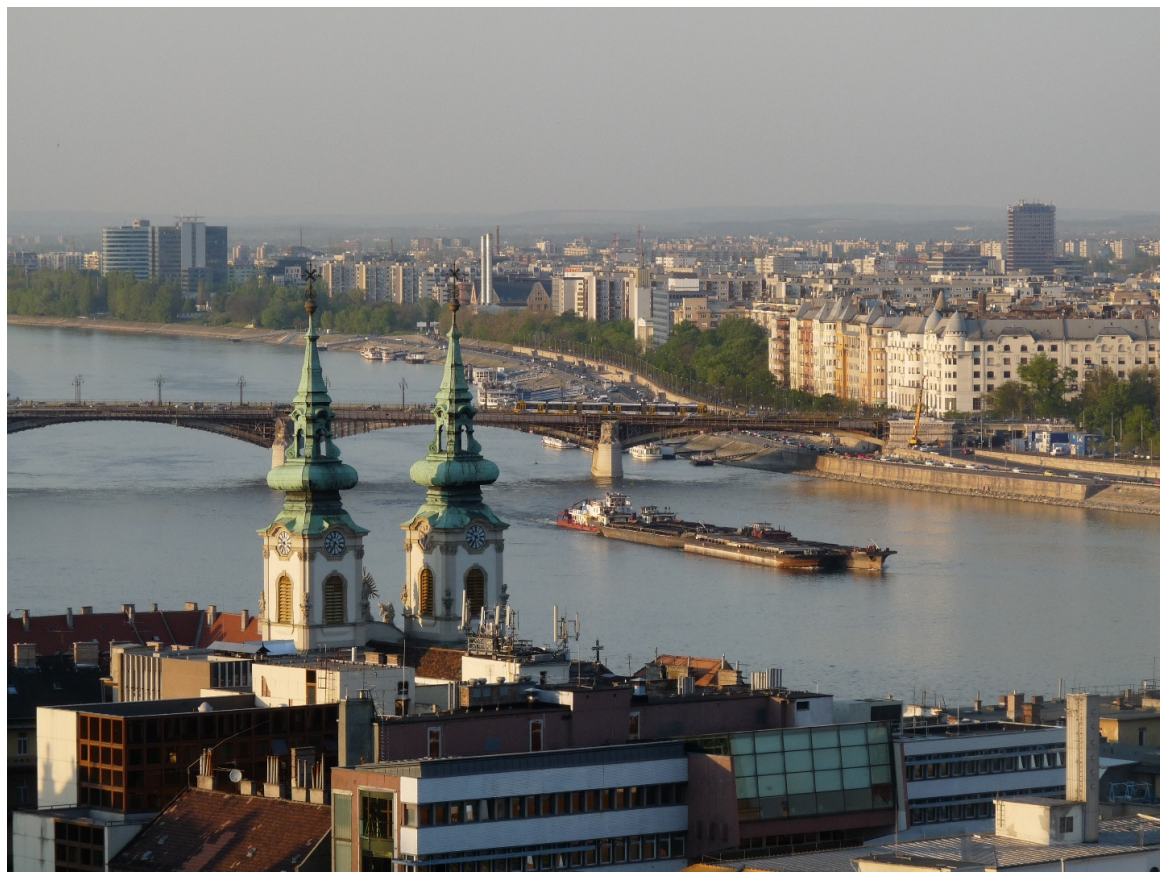

Figure 6. Danube River with barge traveling under bridge at Budapest. Photograph by Patricia Krug. 
tremendous increase in pollutants the river has nearly become unfit for irrigation and is no longer used for drinking water. Pollution has also diminished the once-rich fishing grounds on the main stem of the Danube. Fishing still occurs in the tributary lakes and swamps.

\subsection{Ecology and Environment}

The International Commission for Protection of the Danube River [6] consists of 14 member states (Germany, Austria, the Czech Republic, Slovakia, Slovenia, Hungary, Croatia, Bosnia and Herzegovina, Serbia, Bulgaria, Moldova, Romania, Montenegro, and Ukraine). The ICPDR established programs for the whole Danube river basin including tributaries and groundwater resources [6]. The Commission's goal is to promote and coordinate sustainable and equitable water management including conservation, improvement and rational use of waters and the implementation of the EU Water Framework Directive [7].

\subsection{Transport}

The Danube was an important $19^{\text {th }}$ century waterway but it was annually swept by ice that could lift a large ship out of the water or break ships in two. The Danube "Corridor VII" is still an important EU transport route [7]. After the opening of the Rhine-Main-Danube Canal which connects the Port of Rotterdam and the industrial centers of Western Europe with the Black Sea and connected through the Danube-Black Sea Canal with the Port of Constanta.

The Danube has been partly canalized in Germany (5 locks) and Austria (10 locks) and is designed for large-scale inland vessels $(110 \times 11.45 \mathrm{~m})$. Proposals to build several new locks have not been implemented due to environmental concerns. Canalization of the Danube was limited by the Freudenau locks in Vienna, the Gabcikovo dam and locks near Bratislava and the two double Iron Gate locks between Serbia and Romania. The river is free flowing from the Iron Gate (Figure 4) to the Black Sea, more than $860 \mathrm{~km}$.

The Rhine-Main-Danube Canal at Kelheim connects the Donaukanal in Vienna with the Danube-Black Sea Canal at Cernavoda. The only major navigable rivers linked to the Danube are the Drava, Sava and Tisa. In Serbia, the Danube-TisaDanube Canals network connects to the Danube. A type of flat-bottomed boat called a Zillen was developed for use along the Austrian and German sections of the Danube. The Zillen is still used today for fishing, ferrying, and other transport.

\subsection{Fishing}

Fishing on the Danube, once important in the Middle Ages, is now dramatically reduced although some fishermen are still active on the river tributaries and fishing is still an important industry in the Danube Delta. The Upper Danube ecoregion has about 60 fish species and the Lower Danube-Dniester ecoregion has more than 120 species. There are six sturgeon species including beluga (Del- 
phinapterus leucas), Russian sturgeon (Acipenser gueldenstaedtu), sterlet (Acipenser rutenus), bastard sturgeon (Acipenser nudiventis), starry sturgeon (Acipenser stellatus) and European sea sturgeon (Acipenser sturio). The sturgeon have nearly disappeared from the river. The huchen (Hucho hucho) is endemic to the Danube basin [8].

\subsection{Recreation}

Important natural spots along the Danube include the Wachau Valley, Gemenc in Hungary, the Naturpark Obere Donau in Germany, the National Park Donau-Auen in Austria, Kopacki in Croatia, Iron Gate in Serbia and Romania, the Danube Delta in Romania, and the Srebarna Nature Reserve in Bulgaria. Travel cruises (Figure 7) on the river are important. In addition to the frequented route between Vienna and Budapest some ships travel between Passau in Germany to the Danube Delta. During the peak season, more than 70 cruise liners (Figures 7-10) are in use on the river. The headwaters section of the Danube can only be traversed with canoes or boats [2]. The Danube region is culturally and historically significant due to its landmarks and sights. There is well established infrastructure for cycling and hiking and other travel possibilities. The Danube attracts an international clientele. In Austria there are more than 14 million overnight lodgings and about 6.5 million arrivals per year.

The Danube Banks in Budapest (Figure 10) are a part of UNESCO World Heritage sites which can be viewed from a number of sightseeing cruises. The Danube Bend is also a popular cruise destination. The Danube Cycle Path is a bicycle trail along the river. It is one of the 10 most popular bike trails in Germany [4]. The Danube Bike Trail parallels the Danube from the headwater to the

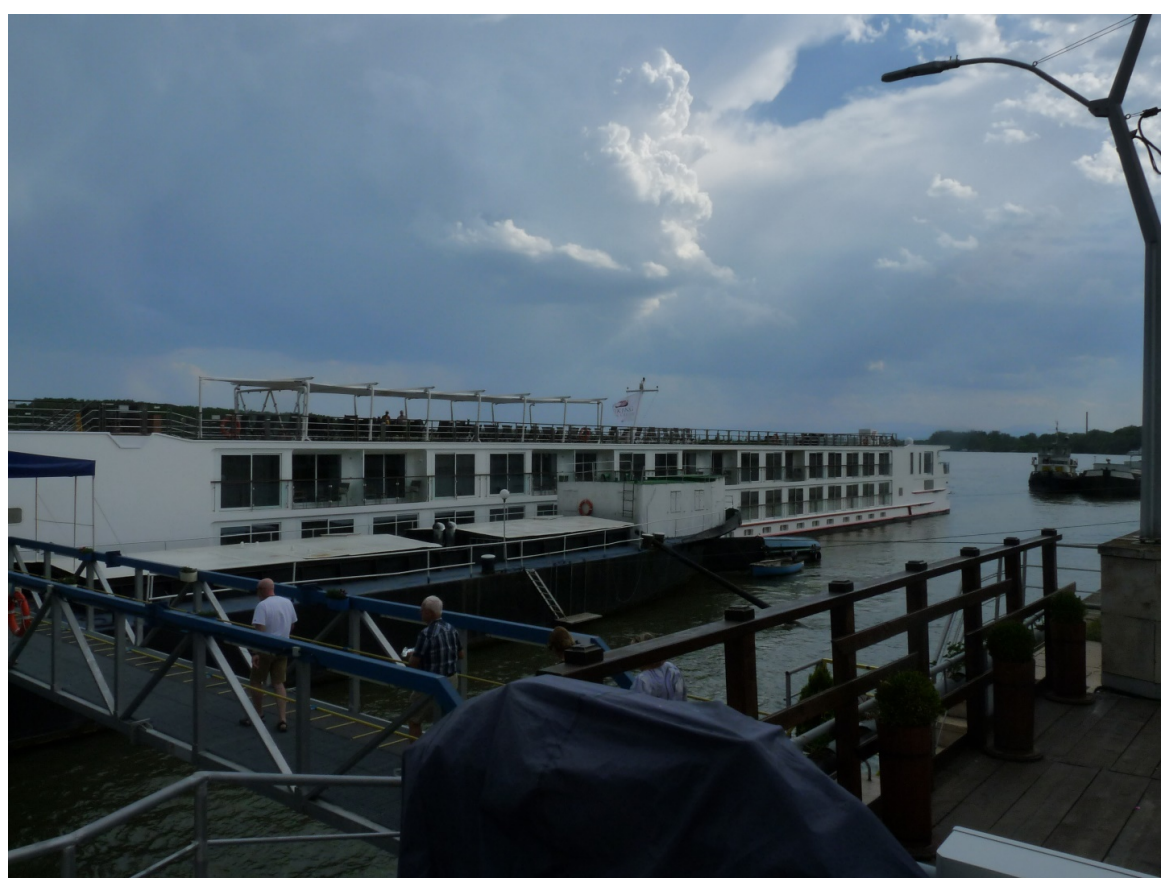

Figure 7. Tourist boarding a cruise ship on the Danube. Photograph by Patricia Krug. 


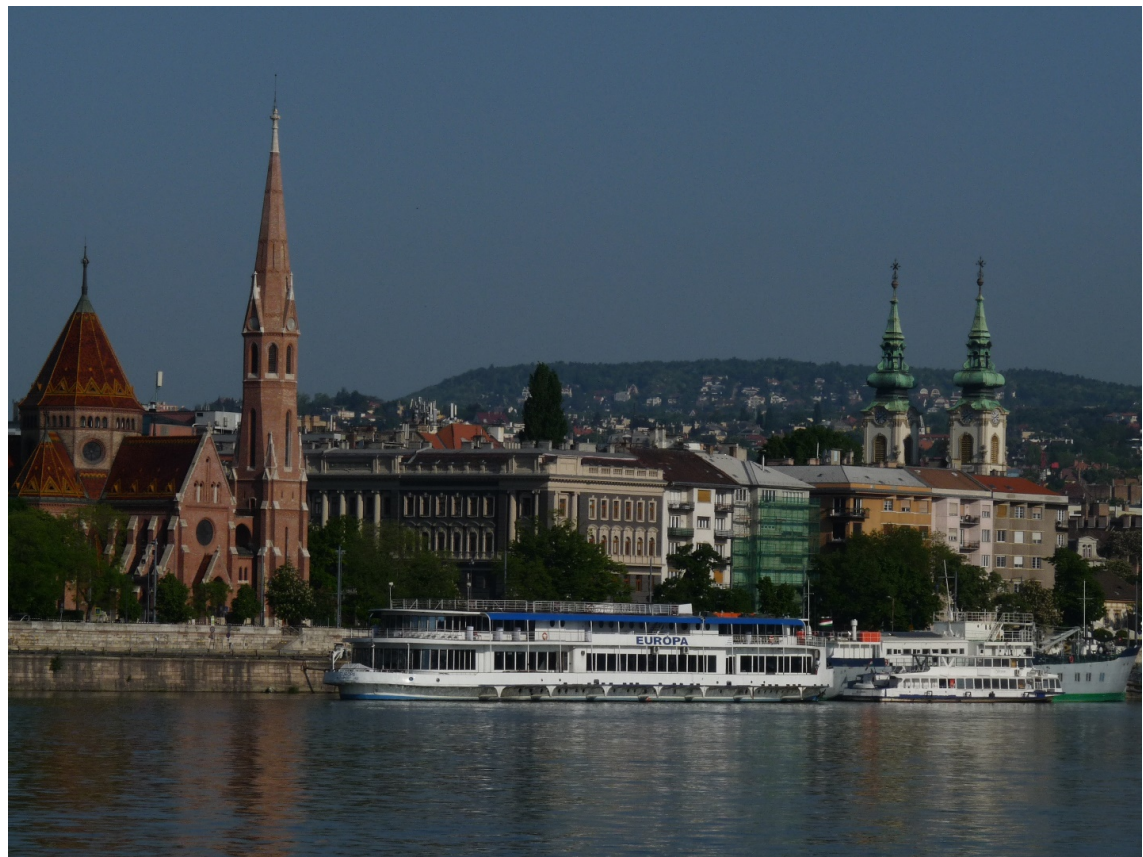

Figure 8. Town and tour boats on the Danube River. Photograph by Patricia Krug.

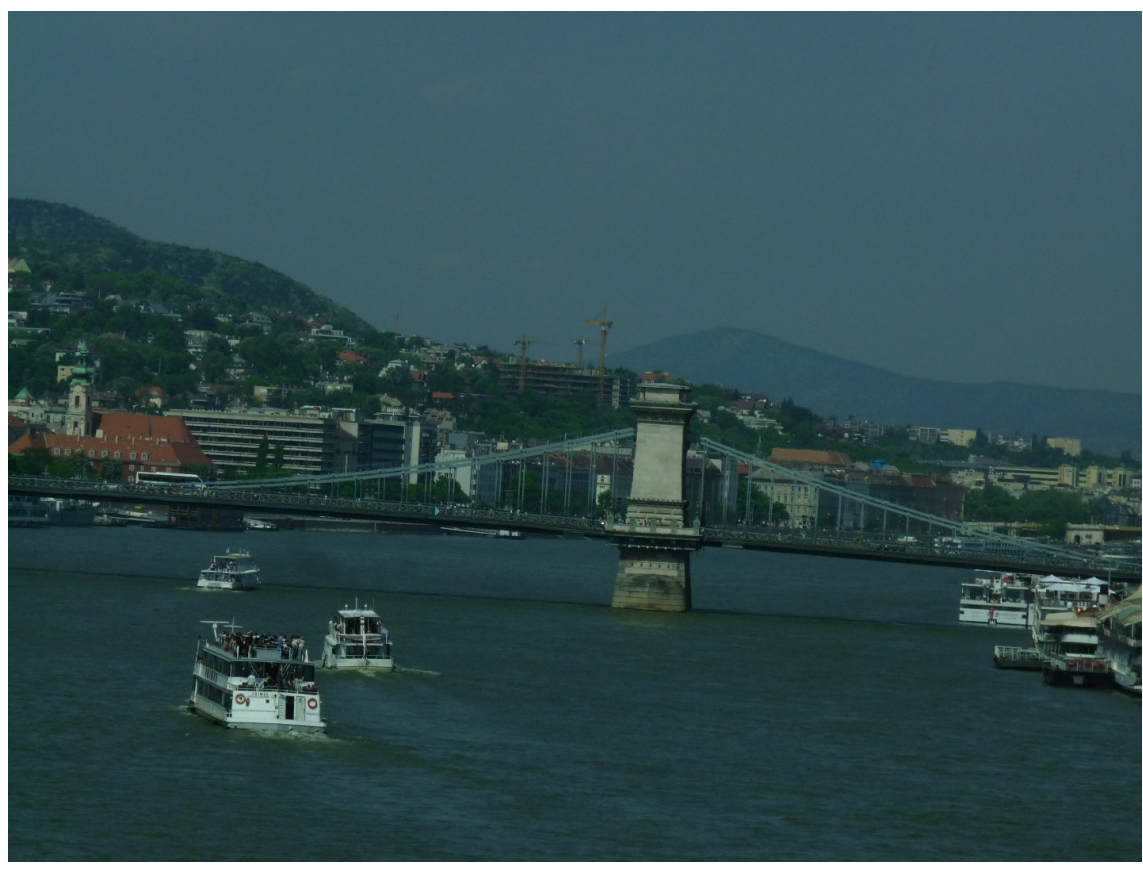

Figure 9. Recreational boats traveling under a bridge along the Danube. Photograph by Patricia Krug.

Black Sea. It is divided into four segments: Donaueschingen-Passac (559 km), Passau-Vienna (340 km), Vienna-Budapest (306 km), and Budapest-Black Sea $(1670 \mathrm{~km})$.

\subsection{Sultans Trail}

The hiking Sultans Trail runs along the river between Vienna and Smederevo in 


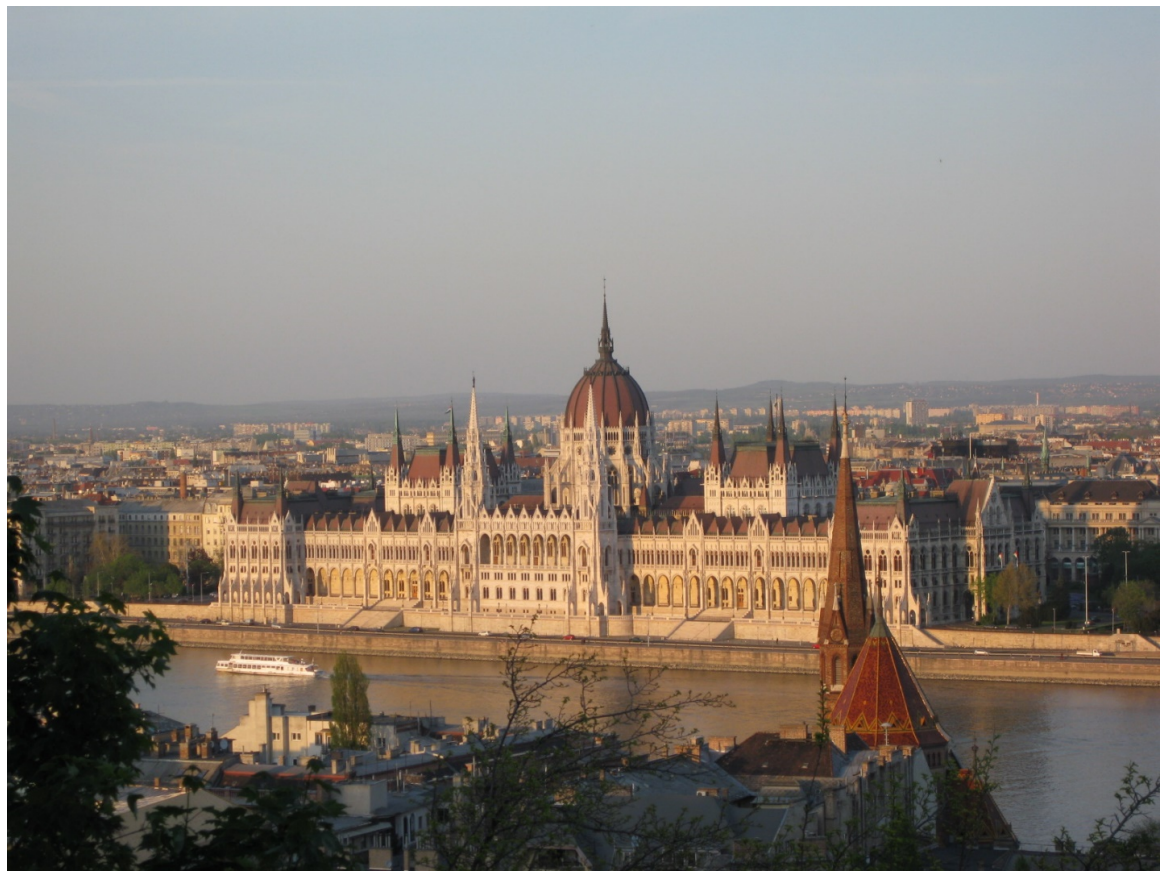

Figure 10. Government building on the Danube River in Budapest. Photograph by Patricia Krug.

Serbia and then leaves the Danube, terminating in Istanbul. Sections along the river are as follows: Vienna-Budapest $(323 \mathrm{~km})$ and Budapest-Smederevo (595 $\mathrm{km})$. In 2010 the $450 \mathrm{~km}$ Donausteig, another hiking trail, was opened from Passau to Grein. The route passes five Bavarian and 40 Austrian communities.

\subsection{Drinking Water}

The Danube is a source of drinking water for about 20 million people. Drinking water comes from purified Danube water. Cities such as Ulm and Passau, also use some water from the Danube [1]. In Austria and Hungary, most water is drawn from ground and spring sources. Most countries find it too difficult to clean the river water because of extensive urban and agricultural pollution. In the Danube Delta of Romania the water is cleaner and cities, like Sulina, a free port at the mouth of the Danube, still obtain drinking water on a regular basis from the Danube. Sulina has been occupied for 7 centuries, although it has been losing population during the last decade perhaps as a result of periodic flooding and the river drinking water becoming more polluted.

\section{Conclusions}

The historic Danube was used by the Ottoman and Roman Empires as a boundary river. Its riverbanks are lined with castles and fortresses that had been used to protect the empires from invading forces. The Danube became the southwestern and central European trade route, most of which is navigable. The Danube headwaters are being captured by the Rhine River via limestone sinkholes and underground river flows. This is a classic example of stream or river capture. 
The Danube flows through 10 countries and has a watershed which includes parts of 19 countries which making it difficult to address historic navigation, flooding and trade challenges. Eventually a Danubian Commission was created by 9 of the 10-river flow through watershed countries. The Danube delta, the largest in Europe and located in Romania and Ukraine, extends into the Black Sea. The Danube Delta is one of the least urbanized major deltas of the world.

The natural and anthropic risks to the Danube River including stream capture, settlement, invasions, navigation and trade. Environmental risks include pollution, industrial and urban wastewater, over fishing, a threat to food supply, urban development, locks and dams, shoreline erosion, flooding.

\section{Acknowledgements}

Published with funding support from USDA, NIFA, Water Division, the Department of NRES, and the Director of the Illinois Office of Research, College of Agricultural, Consumer, and Environmental Science, University of Illinois, Urbana.

\section{Conflicts of Interest}

The authors declare no conflicts of interest regarding the publication of this paper.

\section{References}

[1] Pencev, P.G. and Pinka, P.G. (2020) Danube River. Encyclopedia Britannica. http://www.britannica.com/place/Danube-River

[2] Fermor, P.L. (1986) Between the Woods and Water. On Foot to Constantinople from the Hock of Holland. The Middle Danube to the Iron Gates. New York Viking.

[3] Hales, J. (2013) Upper Danube. Freshwater Ecoregions of the World.

[4] Magris, C. (1999) Danube: A Sentimental Journey from the Source to the Black Sea. Harvey Press, London.

[5] United Nations Economic Commission for Europe (2007) Our Waters: Joining Hands Across Borders. First Assessment of Transboundary Rivers, Lakes and Groundwaters.

[6] IPCDR (2007) Danube River Basin District, Part A-Roof Report, 8.

[7] International Association of Water Supply Companies in the Danube River (2012).

[8] Froese, R. and Pauly, D., Eds. (2013) "Hucho hucho" in FishBase. 